\title{
Gas within the stomach wall and hepatic portal vein
}

\author{
Yoshitaka Tomoda, Satoshi Kagawa, Satoshi Kurata, Kazutoyo Tanaka
}

General Medicine, Saiseikai Fukuoka General Hospital, Fukuoka, Japan

\section{Correspondence to} Dr Yoshitaka Tomoda, yoshisoph@gmail.com

Accepted 20 June 2018

\section{DESCRIPTION}

An 80-year-old woman was admitted to our hospital due to abdominal discomfort. She was diagnosed with amyotrophic lateral sclerosis 6 years ago; 4 years ago, she underwent gastrostomy and was on home mechanical ventilation. She had severe constipation. Two days before admission, she underwent an abdominal massage manually in a circular clockwise motion along the colon structure to encourage defaecation.

On admission, her vital signs were normal. Abdominal examination revealed hypoactive bowel sounds. Laboratory findings revealed mild leucocytosis and normal lactate levels. Contrast-enhanced abdominal CT revealed intramural air in the stomach and extensive hepatic portal venous gas (figure 1). Surgical consultation was performed, and conservative management was undertaken on the basis of the stable vital signs and the unlikelihood of bowel ischaemia. After 24 hours, the abnormal gas was markedly resolved (figure 2). Upper endoscopy 72 hours after admission showed only mild gastritis, confirming the diagnosis of gastric pneumatosis.

Gastric pneumatosis is an unusual condition in which gas is present in the stomach wall. It comprises two contrasting diseases: gastric emphysema and emphysematous gastritis. Gastric emphysema is a benign, spontaneous condition that is caused by an injured mucosa due to intraluminal high pressure or trauma. ${ }^{1}$ Emphysematous gastritis is a life-threatening disease caused by infection with gas-forming bacteria. Mortality is high (60\%-80\%), and early recognition of emphysematous gastritis is crucial. It can be distinguished from gastric emphysema by the presence of poor vital signs, severe abdominal pain and high lactate levels.

Hepatic portal venous gas is also an unusual and serious finding, and is most commonly associated with intestinal ischaemia. The differential

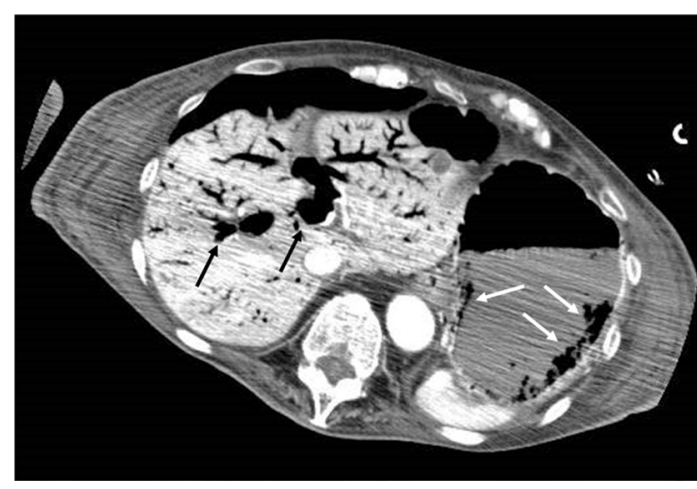

Figure 1 Abdominal CT image showing intramural air in the stomach (white arrows) and massive hepatic portal venous gas (black arrows).

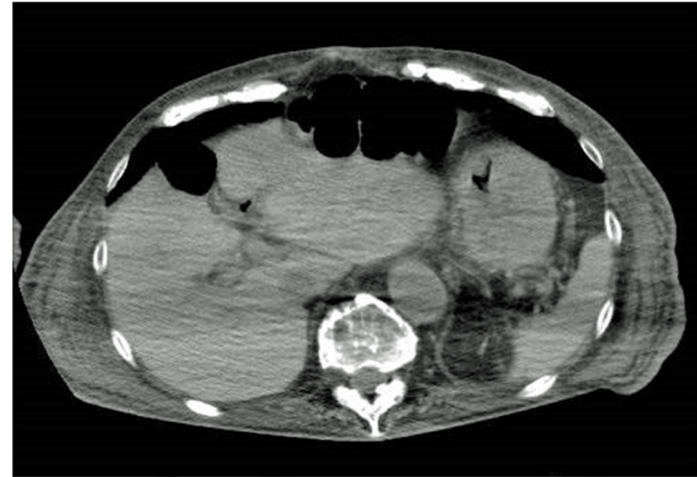

Figure 2 Abdominal CT image after 24 hours showing resolution of abnormal gas.

diagnosis is pneumobilia, but it can be distinguished from pneumobilia by the distribution of gas. Hepatic portal venous gas is associated with peripheral gas distribution (within $2 \mathrm{~cm}$ beneath the liver capsule), whereas gas in pneumobilia is centrally distributed. ${ }^{2}$ Gastric pneumatosis and hepatic portal venous gas are often associated and are being identified more frequently due to increased use of CT.

Standard treatment for this condition is not available. Gastric emphysema is benign and resolves spontaneously even without specific treatment. Alternatively, pneumatosis intestinalis with hepatic portal venous gas is a high-risk factor for bowel ischaemia, which has a high mortality. Although some cases have been resolved by conservative management, ${ }^{3}$ clinicians should not underestimate the need for surgical consultation.

Learning points

- Gastric pneumatosis is a rare condition that refers to the presence of gas within the stomach wall.

- Gastric pneumatosis comprises two contrasting conditions: benign gastric emphysema and lifethreatening emphysematous gastritis.

- Gastric pneumatosis with hepatic portal venous gas is a high-risk factor for bowel ischaemia.

- In principle, surgical consultation is necessary; however, there are cases in which the symptoms have spontaneously resolved by conservative treatment.

Contributors YT drafted and edited the manuscript. SKa and SKu drafted the initial manuscript. KT critically reviewed the manuscript. All authors approved the final manuscript and agree to be accountable for all aspects of the work.

Competing interests None declared.

Patient consent Obtained. 


\section{Images in...}

Provenance and peer review Not commissioned; externally peer reviewed.

\section{REFERENCES}

1 Agha FP. Gastric emphysema: an etiologic classification. Australas Radiol 1984;28:346-52.
2 Abboud B, El Hachem J, Yazbeck T, et al. Hepatic portal venous gas: physiopathology, etiology, prognosis and treatment. World J Gastroenterol 2009;15:3585-90.

3 Tang CM, Yarandi SS, Laxton WH, et al. Conservative management of gastric emphysema with hepatoportal venous gas. BMJ Case Rep 2015;2015: bcr2015211669.

Copyright 2018 BMJ Publishing Group. All rights reserved. For permission to reuse any of this content visit http://group.bmj.com/group/rights-licensing/permissions.

BMJ Case Report Fellows may re-use this article for personal use and teaching without any further permission.

Become a Fellow of BMJ Case Reports today and you can:

- Submit as many cases as you like

- Enjoy fast sympathetic peer review and rapid publication of accepted articles

- Access all the published articles

Re-use any of the published material for personal use and teaching without further permission

For information on Institutional Fellowships contact consortiasales@bmjgroup.com

Visit casereports.bmj.com for more articles like this and to become a Fellow 